Jurnal Pengabdian Masyarakat Sains Indonesia

\title{
Penulisan Artikel Ilmiah Sebagai Upaya Peningkatan Profesionalisme Guru Kimia SMA di Kota Mataram
}

\author{
Syarifa Wahidah Al Idrus ${ }^{1 *}$, Yunita Arian Sani Anwar ${ }^{1}$, Aliefman Hakim ${ }^{1}$, Saprizal $^{1}$ \\ ${ }^{I}$ Program Studi Pendidikan Kimia, FKIP Universitas Mataram, Mataram, Indonesia.
}

DOI: https://doi.org/10.29303/.jpmsi.v2i1.34

Citation: Idrus., S. W. A., Anwar, Y. A. S., Hakim, A., Saprizal. 2020. Penulisan Artikel Ilmiah Sebagai Upaya Peningkatan Profesionalisme Guru Kimia SMA di Kota Mataram. Jurnal Pengabdian Masyarakat Sains Indonesia (JPMSI). 2(1): 84-88.

Article history

Received: Mei $14^{\text {th }} 2020$

Revised: Mei $18^{\text {th }} 2020$

Accepted: Mei $28^{\text {th }} 2020$

*Corresponding Author: Syarifa Wahidah Al Idrus, FKIP Universitas Mataram, Mataram, Indonesia;

Email:

Syarifaidrus@unram.ac.id

\begin{abstract}
Abstrak: Pengabdian ini bertujuan untuk memberikan pelatihan dan pendampingan penulisan artikel ilmiah dalam bentuk jurnal ilmiah pada guru kimia sekota Mataram. Pelaksanaan dilakukan di SMAN 2 Mataram. Kegiatan ini diharapkan dapat menjalin kemitraan dengan sekolah sasaran dan menginisiasi kemitraan dengan sekolah lain untuk meningkatkan kualitas professional guru.. Kegiatan ini diawali dengan pembekalan penulisan artikel ilmiah dilanjutkan dengan pelatihan penulisan dan pengiriman jurnal serta proses pendampingan hingga jurnal siap dikirim ke jurnal.. Dari 12 orang peserta, 6 orang telah mempunyai ide untuk menulis dan 1 orang guru telah siap artikel untuk diterbitkan pada bulan November 2019 pada jurnal CEP (chemistry education practice). Hasil kegiatan menunjukkan antusias guru dalam melaksanakan semua tahapan kegiatan. Mereka berharap lebih sering dilakukan kegiatan kegiatan seperti ini untuk meningkatkan professional guru. Tanggapan guru pelajaran kimia menunjukkan respon positif terhadap kegiatan ini.
\end{abstract}

Kata Kunci : Pelatihan, Artikel Ilmiah, Pendampingan

\section{Pendahuluan}

Sistem pendidikan nasional menjadikan guru sebagai salah satu pilar utama. Kesuksesan dari suatu proses pembelajaran merupakan cerminan dari kualitas dan keseriusan para guru yang mengasuhnya. Guru memegang peranan penting dalam peningkatan kompetensi diri untuk menjadi guru profesional. Salah satu kompetensi yang harus dimiliki oleh guru adalah menyampaikan informasi di forum-forum ilmiah terkait dengan berbagai pemikiran dan penelitian yang dilakukan. Penelitian yang dilakukan guru mempunyai peranan yang penting dalam meningkatkan kualitas belajar mengajar di sekolah.

Peningkatan dan perbaikan kualitas belajar perlu dilakukan guru dengan cara melakukan penelitian penelitian tindakan kelas dan dapat dilaporkan dalam bentuk artikel ilmiah yang ditulis dibeberapa jurnal. Menulis artikel ilmiah di jurnal merupakan salah satu bentuk pengembangan profesi guru. Penulisan artikel ilmiah semacam ini diyakini dapat meningkatkan kemampuan profesionalisme guru sekaligus memperbaiki kualitas pembelajaran yang disampaikannya. Dari hasil observasi dibeberapa sekolah terungkap bahwa salah satu kelemahan guru di NTB yaitu masih kurangnya penelitian dan karya ilmiah. Kondisi ini terjadi karena kegiatan menulis merupakan hal yang dianggap sulit oleh sebagaian besar guru guru di sekolah mulai dari tingkat guru sekolah dasar sampai guru SMA.

Selain meningkatkan kemampuan profesionalisme guru, menulis pada artikel ilmiah juga merupakan peraturan administrasi yang harus dipenuhi oleh guru, karena tanpa artikel para guru tidak akan mendapatkan hak nya dalam hal kenaikan pangkat. Admisnitrasi kepegawaian membuat artikel ilmiah menjadi salah satu syarat untuk naik pangkat sehingga menjadi suatu keharusan bagi para guru jika akan naik pangkat dari golongan IVa ke IV b dan seterusnya. Pada masa-masa yang akan datang, kemampuan untuk membuat artikel ilmiah ini menjadi prasyarat yang 
Idrus et al, Jurnal Pengabdian Masyarakat Sains Indonesia 2020, 2 (1):84-88 DOI : https://doi.org/10.29303/ipmsi.v2i1.34

harus dimiliki oleh setiap guru. Peraturan Menteri

Negara Pendayagunaan Aparatur Negara dan Reformasi Birokrasi Nomor PER/16/M.PAN-RB/11/2009 tentang Jabatan Fungsional Guru dan Angka Kreditnya semakin menegaskan pentingnya artikel ilmiah ini (Peraturan Bersama Mendiknas dan Kepala BKN No 14 tahun 2010, Peraturan Manteri Pendidikan Nasional Nomor 35 Tahun 2010). Kenaikan pangkat dari golongan III/b ke III/c dan golongangolongan selanjutnya mensyaratakan paling sedikit empat angka kredit dari sub unsur publikasi ilmiah dan/atau karya inovatif.

Persyaratan dalam bentuk artikel ini banyak menghambat para guru untuk naik pangkat. Pada dasarnya setiap guru telah memiliki kompetensi keterampilan dalam aspek bahasa, yaitu berbicara, karena guru setiap hari harus berkomunikasi dengan peserta didik. Sementara itu, kondisi yang ada keterampilan berbicara yang dimiliki guru belum seimbang dengan keterampilan menulis. Guru kesulitan untuk menentukan topik, mengawali suatu tulisan, dan mengembangkannya dalam bentuk tulisan yang padu. Untuk itu perlu dilakukan pelatihaan penulisan artikel ilmiah dalam bentuk laporan penelitian maupun penulisan artikel dalam jurnal ilmiah. Dengan demikian, soft skill keterampilan menulis guru dapat meningkat seiring dengan pemenuhan prasyarat pengusulan kenaikan pangkat.

Menulis karya ilmiah atau artikel ilmiah juga merupakan permasalahan yang dihadapi guru guru SMA dalam hal ini guru kimia SMA di kota Mataram. Beberapa guru tertahan digolongannya sampai beberapa tahun karena belum mampu menyusun artikel ilmiah sebagai syarat naik pangkat. Kondisi ini sangat memprihatinkan, Program studi kimia FKIP Universitas Mataram perlu ikut memberikan perhatian sebagai program studi yang mencetak calon guru kimia. Bentuk perhatian yang dilakukan sebagai bentuk pengabdian pada masyarakat.

Peningkatan mutu pendidikan dapat dicapai

melalui beberapa cara, antara lain melalui peningkatan kualifikasi tenaga kependidikan, pelatihan dan pendidikan, atau dengan memberikan kesempatan kepada tenaga kependidikan lewat pelatihan terkendali (Anonimous, 2003). Dengan kondisi tersebut, perlu untuk dilakukan bimbingan bagi para guru dalam membuat karya tulis ilmiah
e-ISSN : 2715-2537

p-ISSN : 2715-2545

(Artikel) . Untuk itu kami mengajukan untuk mengadakan kegiatan Pelatihan Penulisan Artikel Ilmiah bagi para guru, khsususnya guru-guru kimia SMA Kota Mataram.

\section{Metode}

Metode pelaksanaan kegiatan berupa pelatihan. Kegiatan pelatihan penulisan artikel ilmiah dilakukan dengan langkah-langkah sebagai berikut.

\section{a. Berkoordinasi dengan MGMP Kimia kota Mataram.}

Penulis berkoordinasi dengan pengurus MGMP Kimia kota Mataram berkaitan dengan kegiatan pelatihan, terutama mengenai tempat dan jadwal pelaksanaan. Pengurus MGMP diharapkan dapat membantu penulis menyiapkan prasarana dan sarana penunjang pelaksanaan kegiatan pelatihan. Pengurus MGMP juga menyurati anggota MGMP untuk menjadi peserta dalam kegiatan pelatihan.

b. Pelatihan pencarian informasi atau browsing internet.

Kegiatan ini diawali dengan pemberian informasi atau pembekalan kepada seluruh peserta tentang cara-cara dan trik-trik cepat pencarian informasi yang berkaitan dengan artikel jurnal, buku, makalah, materi bidang studi, animasi dan video pembelajaran, dan sebagainya di internet. Setelah pembekalan, seluruh peserta berlatih mengakses informasi di internet.

c. Pembekalan penulisan artikel ilmiah.

Pembekalan penulisan artikel ilmiah meliputi tentang pedoman penulisan pada jurnal CEP pendidikaan kimia FKIP Unram dan jurnal lain yang ada di FKIP UNRAM. Untuk artikel hasil penelitian, cakupan materinya meliputi kriteria judul, identitas penulis, abstrak, pendahuluan, metode penelitian, hasil dan pembahasan, penutup, dan daftar rujukan. Sementara itu, untuk artikel kajian putaka atau hasil gagasan, cakupan materinya meliputi kriteria judul, identitas penulis, abstrak, pendahuluan, pembahasan, penutup, dan daftar rujukan.

Kegiatan Pelatihan Penulisan artikel ilmiah dilakukan dengan menggunakan metode seperti berikut.

\section{Ceramah}

Materi yang diberikan adalah penjelasan tentang motivasi untuk menulis karya ilmiah, etika 
Idrus et al, Jurnal Pengabdian Masyarakat Sains Indonesia 2020, 2 (1):84-88 DOI : https://doi.org/10.29303/ipmsi.v2i1.34

penulisan karya ilmiah, teknik penulisan karya ilmiah, kebahasaan dalam ragam karya ilmiah, penelusuran referensi melalui internet, penyusunan karya ilmiah, dan teknik swasunting.

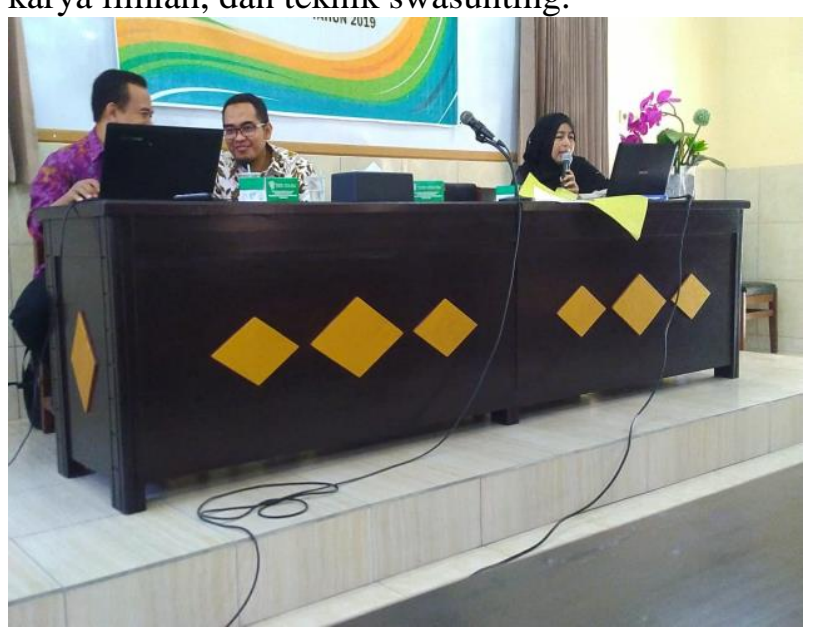

\section{Diskusi}

Pada tiap materi yang disampaikan, peserta dapat berdialog dan berdiskusi dengan tim Pengabdian.

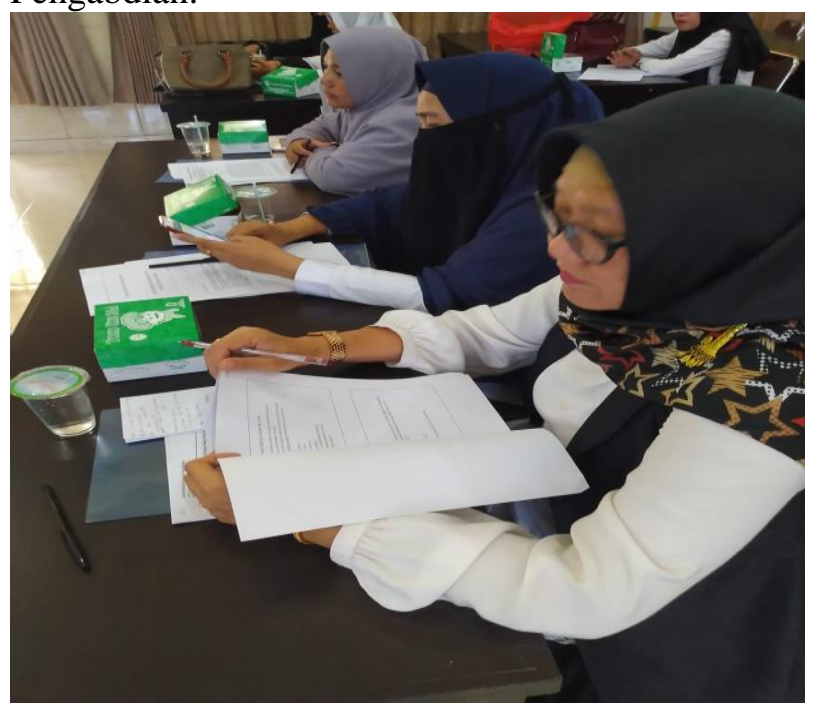

\section{Praktek Menulis}

Peserta diminta untuk melakukan praktek/latihan menulis. Peserta akan dikelompokkan berdasarkan kemampuan menulis yang telah dimilikinya. Tingkat kesulitan dari praktek ini disesuaikan dengan kemampuan masing-masing perserta. Pada bagian akhir peserta akan diberi tugas untuk membuat artikel berdasarkan bidang keahlian masing masing. Artikel ini merupakan syarat untuk memperoleh sertifikat peserta.
e-ISSN : 2715-2537

p-ISSN : 2715-2545

Pelaksanaan penulisan artikel ilmiah dirancang enam kali dalam bentuk tatap muka atau online. Kegiatan tatap muka diwujudkan dalam bentuk pelatihan artikel yang diawali dengan menggali ide-ide yang menarik untuk dijadikan topik dalam artikel. Selanjutnya, masing-masing perserta mengembangkan ide sesuai dengan tata urutan dalam penulisan artikel. peserta. Setelah direvisi peserta melanjutkan penyusunan artikel sesuai dengan sistematika yang telah disampaikan nara sumber. Sebagimana yang disarankan oleh Hand dan Prain (2002), kegiatan magang/ pendampingan akan memberikan dampak yang lebih efektif. Tahapan dalam penulisan artikel sebagai berikut:
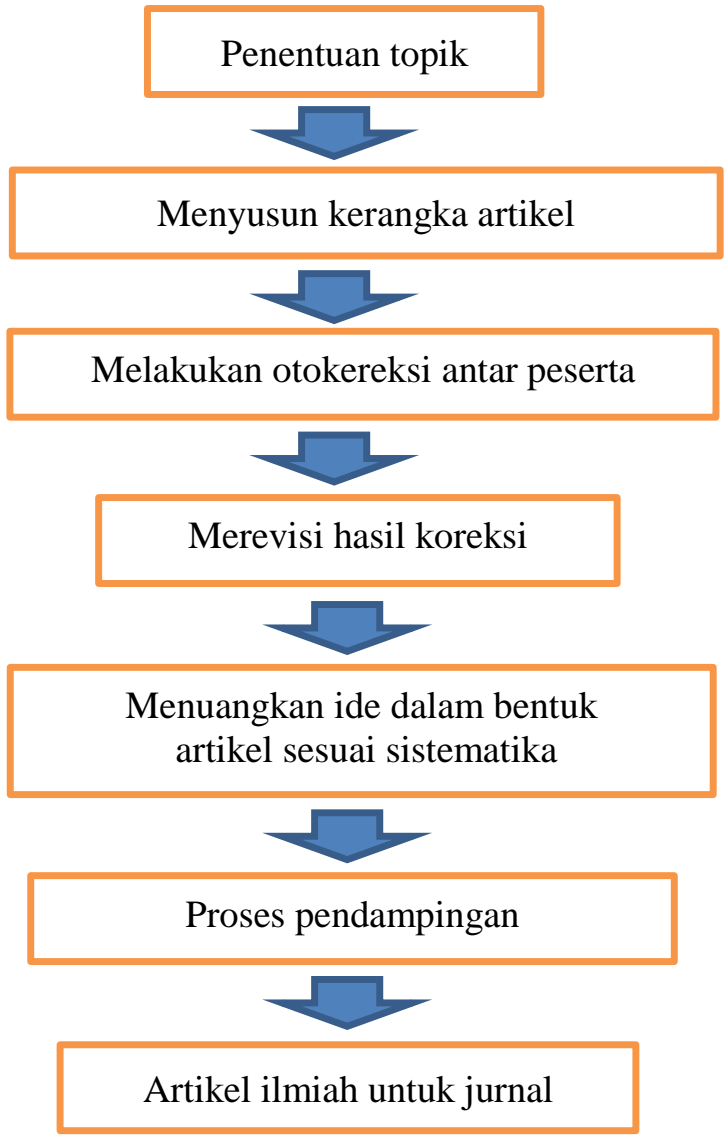

Bagan 1. Tahap tahap penyusunan artikel penelitian

\section{Hasil dan Pembahasan}

Kemampuan guru guru kimia kota Mataram dalam menulis artikel ilmiah dalam jurnal lokal dan nasional berdasarkan hasil 
Idrus et al, Jurnal Pengabdian Masyarakat Sains Indonesia 2020, 2 (1):84-88 DOI : https://doi.org/10.29303/ipmsi.v2i1.34

observasi masih sangat rendah. Rendahnya kemampuan guru ini disebabkan tidak pernah dilakukan pengenalan tentang penulisan artikel ilmiah terutama jurnal ilmiah. Guru hanya fokus pada kegiatan proses pembelajaran tanpa mencoba mengembangkan profesional diri pada kompetensi yang lain. Menulis artikel ilmiah merupakan salah satu bentuk dari kegiatan pengembangan profesi guru. Pengembangan profesi terdiri dari 5 (lima) macam kegiatan, yaitu: (1) menyusun Karya Tulis Ilmiah (KTI), (2) menemukan Teknologi Tepat Guna, (3) membuat alat peraga/bimbingan, (4) menciptakan karya seni dan (5) mengikuti kegiatan pengembangan kurikulum. Guru sebagai salah satu masyarakat akademik diharapkan mampu untuk mengembangkan ilmu pengetahuan dan teknologi serta pemecahan berbagai permasalahan yang dihadapi masyarakat (Santosa, 2007: 1).

Kegiatan pengabdian telah dilakukan dengan memberikan pelatihan penulisan artikel ilmiah bagi guru kimia SMA di Kota Mataram. Kegiatan ini diawali dengan proses persiapan, dilanjutkan dengan kegiatan pelatihan. Kegiatan pelatihan ini dilakukan dengan metode ceramah. Materi pertama yang disampaikan dalam pelatihan ini adalah tentang artikel ilmiah, etika penulisan artikel ilmiah, bagian bagian dari artikel ilmiah serta langkah langkah penulisan artikel ilmiah. Materi pertama ini sangat penting, karena merupakan langkah awal dalam penulisan artikel ilmiah. Artikel ilmiah merupakan tulisan yang berisi gagasan kreatif yang disusun secara komprehensif berdasarkan data akurat, dianalisis secara runtut, tajam dan diakhiri dengan kesimpulan yang relevan. Oleh sebab itu, materi dan isi dari penulisan karya tulis ilmiah diharapkan memenuhi aspek-aspek (1) relevan dengan situasi dan kondisi yang ada, (2) mempunyai pokok permasalahan yang jelas, (3) masalah dibatasi, sesempit mungkin (Firmansyah, 2007). Adapun tujuan penulisan karya tulis ilmiah adalah memberikan pemahaman terhadap guru agar dapat berpikir
e-ISSN : $2715-2537$

p-ISSN : 2715-2545

secara logis dan ilmiah dalam menguraikan dan membahas suatu permasalahan serta dapat menuangkannya secara sistematis dan terstruktur.

Materi kedua yang disampaikan adalah tentang tamplate beberapa jurnal FKIP UNRAM dan langkah langkah dalam masuk ke jurnal yang akan dituju. Pengenalan beberapa jurnal kepada guru kimia SMA kota Mataram, merupakan suatu hal yang penting untuk membuka wawasan guru tentang beberapa jurnal yang bisa dituju dan disesuaikan dengan tema artikel yang telah dibuat. Kurniadi (2017) mengungkapkan bahwa cara penulisan, karya tulis ilmiah harus tunduk pada gaya selingkung di lembaga induknya. Adapun syarat keilmiahan suatu karya yaitu menyajikan fakta objektif, ditulis secara cermat, tepat, benar, jujur, dan tidak bersifat tekanan, serta disusun secara sistematis, menyajikan penalaran sebabakibat/akibat-sebab, mengandung pandangan peneliti, dan tanpa manipulasi.

Penyampaian materi dilakukan oleh tim pengabdian dengan jumlah peserta 12 orang guru kimia dari beberapa SMA di kota Mataram yang mengikuti pelatihan, hampir semua guru belum pernah menulis artikel ilmiah. Hal ini disebabkan guru guru tersebut merasakan menulis merupakan suatu hal yang tidak mudah dan tidak ada upaya dari sekolah untuk memberikan pelatihan atau peningkatan sumber daya guru dalam hal menulis.

Upaya lanjutan proses pelatihan penulisan dilakukan pendampingan bagi guru kimia selama 3 bulan. Selama proses pendampingan hanya sebagian kecil peserta yang aktif dan dari 12 orang guru kimia di kota Mataram, setelah proses pendampingan selama satu bulan, satu orang guru berhasil membuat artikel ilmiah dan siap di kirim ke CEP (Chemistry Education Practise) jurnal. Minimnya guru yang berhasil membuat jurnal karena hampir semua guru kimia belum punya ide untuk membuat artikel ilmiah. 
Idrus et al, Jurnal Pengabdian Masyarakat Sains Indonesia 2020, 2 (1):84-88 DOI : https://doi.org/10.29303/ipmsi.v2i1.34

\section{Kesimpulan}

Berdasarkan hasil evaluasi terhadap pelaksanaan kegiatan pengabdian ini maka dapat disimpulkan sebagai berikut :

1. Kegiatan pengabdian ini dapat dinyatakan sangat berhasil dengan nilai keberhasilan mencapai $94 \%$. Hal ini ditunjukkan dengan setiap tahapan yang direncanakan dapat dilaksanakan dengan baik dan lancar, meskipun kendalanya hanya saat menyesuaikan alokasi waktu pelaksanaan (hari selasa, 29 Oktober 2019), karena kegiatan berlangsung saat proses belajar mengajar pada minggu tersebut sedang aktif dan mendekati ujian akhir semester.

2. Pengabdian ini sangat bermanfaat tidak hanya bagi siswa tapi bagi guru pembina maupun sekolah. Karena adanya kegiatan semacam ini dapat menambah wawasan keilmuwan dan keterampilan bagi guru. Sedangkan bagi sekolah semakin tinggi minat belajar siswa diharapkan akan memberikan korelasi positif pada peningkatan prestasi belajar siswa. Dengan demikian kegiatan ini diharapkan mampu mendukung pembelajaran kimia dilakukan secara terintegrasi baik di kelas maupun di laboratorium.

\section{Saran}

Perlu dilakukan pengabdian lanjutan dengan topik yang bervariatif dalam upaya meningkatkan wawasan serta pengetahuan siswa serta melakukan kegiatan pada saat kegiatan proses belajar mengajar sedang tidak aktif untuk menghindari terganggunya kegiatan belajar yang sudah dirancang dengan baik.

\section{Daftar Pustaka}

Adijuwana Hendra. 1992. Manajemen Laboratorium. Bogor: Istitut Pertanian Bogor.

Budiono Djoko. 1992. Pengantar Kegiatan Laboratorium Biologi. Surabaya: University Press IKIP Surabaya.
e-ISSN : 2715-2537

p-ISSN : 2715-2545

John W. Hansen \& Gerald G. L. 2004. Developing technology teachers : questioning the industrial tool use model. Journal of Technology Education. 15 (2), 20 - 32.

Mulyono. 2006. Membuat Reagen Kimia. Jakarta: Bumi Aksara.

Padmawinata Djupri, dkk. 1983. Pengelolaan Laboratorium IPA. Dirjen Dikti, Jakarta.

Sudarmadji Slamet, dkk. 1984. Prosedur Analisa untuk Bahan Makanan dan Pertanian. Liberty, Yogyakarta.

Tim. 2002. Pedoman Standar Minimal Pendayagunaan Peralatan Laboratorium Kimia. Jakarta: Direktorat Pendidikan Menengah Umum

Tim. 2004. Penanganan Bahan - bahan Kimia Berbahaya dan Beracun Serta keselamatan Kerja. Bandung: Pusat Penelitian Kimia. 